\title{
PENINGKATAN KESEJAHTERAAN ANGGOTA ZIDAM III/ SILIWANGI MELALUI PENGUATAN KELEMBAGAAN KOPERASI KARTIKA YUDHA KARYA JAYA
}

\author{
Jaka Kartiwa \\ IKIP Siliwangi \\ kartiwa_rdt@yahoo.com
}

\begin{abstract}
ABSTRAK
Penelitian ini bertujuan untuk 1. Untuk mengetahui perencanaan Peningkatan Kesejahteraan Anggota ZIDAM III Siliwangi Melalui Penguatan Kelembagaan Koperasi Kartika Yudha Karya Jaya. 2. Untuk mengetahui proses Peningkatan Kesejahteraan Anggota ZIDAM III Siliwangi Melalui Penguatan Kelembagaan Koperasi Kartika Yudha Karya Jaya. 3. Untuk mengetahui Faktor apa yang mendorong dan penghambat serta hasil dari Peningkatan Kesejahteraan Anggota ZIDAM III Siliwangi Melalui Penguatan Kelembagaan Koperasi Kartika Yudha Karya Jaya. Penelitian ini menggunakan metode penelitian deskriptif kualitatif, dengan tekhnik pengumpulan data melalui observasi, wawancara, dokumentasi dan studi literatur. Hasil penelitian yang diperoleh menunjukkan bahwa peningkatan kesejahteraan Koperasi Anggota ZIDAM III Siliwangi Melalui Penguatan Kelembagaan Koperasi Kartika Yuda tidak hanya berkembang di bidang jasa simpan pinjam saja tetapi juga mengalami perkembangan di bidang usaha photocopy, usaha kantin pegawai, dan lain-lain yang bertujuan untuk memenuhi kebutuhan di instansi Zidam III Siliwangi. Koperasi ini memberikan peranan yang sangat besar dalam mensejahterakan Anggotanya, koperasi sebagai tempat pelatihan pengembangan SDM adalah dengan memberikan pelatihan keterampilan kepada pegawai atau anggota Zidam III Siliwangi. Koperasi sebagai pemberi pinjaman kepada anggota adalah dengan memberikan modal yang dibutuhkan anggota. Faktor pendorongnya adalah adanya peningkatan pengetahuan dan keterampilan, sedangkan faktor penghambatnya adalah anggota/pegawai kurang memahami aturan yang bersangkutan dengan koperasi.
\end{abstract}

Kata Kunci : Penguatan kelembagaan koperasi, Peningkatan kesejaheteraan

\section{PENDAHULUAN}

Undang-Undang Republik Indonesia Nomor 17 Tahun 2012 Tentang Perkoperasian Bahwa pembangunan perekonomian Nasional bertujuan untuk mewujudkan kedaulatan politik dan ekonomi Indonesia melalui pengelolaan sumberdaya ekonomi dalam suatu iklim pengembangan dan pemberdayaan Koperasi yang memiliki peran strategis dalam tata ekonomi nasional berdasarkan asas kekeluargaan dan demokrasi ekonomi dalam rangka menciptakan masyarakat yang maju, adil, dan makmur berlandaskan Pancasila dan Undang-Undang Dasar Negara Republik Indonesia Tahun 
1945. Bahwa pengembangan dan pemberdayaan Koperasi dalam suatu kebijakan Perkoperasian harus mencerminkan nilai dan prinsip Koperasi sebagai wadah usaha bersama untuk memenuhi aspirasi dan kebutuhan ekonomi Anggota sehingga tumbuh menjadi kuat, sehat, mandiri, dan tangguh dalam menghadapi perkembangan ekonomi nasional dan global yang semakin dinamis dan penuh tantangan.Organisasi secara umum merupakan suatu sistem atau kumpulan manusia yang bekerja sama untuk mencapai suatu tujuan tertentu. Jadi suatu organiasi tidak bisa dipisahkan dengan faktor manusia dan tujuan yang hendak dicapai. Tujuan yang akan dicapai suatu organisasi sangat dipengaruhi oleh kualitas pegawai yang ada dalam organisasi tersebut.

Koperasi merupakan kumpulan orang-orang yang bekerja sama memenuhi satu atau lebih kebutuhan ekonomi atau bekerja sama melakukan usaha,maka dapat dibedakan dengan jelas dari badan-badan usaha atau pelakukegiatan ekonomi yang lebih mengutamakan modal. Dengan demikian koperasi sebagai badan usaha mengutamakan faktor manusia dan bekerjaatas dasar perikemanusiaan bagi kesejahteraan para anggotanya. Meskipunkoperasi merupakan kumpulan dan menjunjung tinggi nilainilaikemanusiaan, tetapi koperasi bukanlah badan amal. Kerjasama dalam masyarakat modern telah nampak wujudnya dalam suatujaringan sistem yang lebih kompleks.

Pelaksanaan pembangunan mengikutsertakan pegawai atau aparatur pemerintah bersama rakyat memegang peranan penting yaitu sebagai pelaksana dalam menjalankan pembangunan dan sebagai penggerak laju pembangunan disegala bidang. Peranan pegawai atau aparatur negara sangat dituntut dalam menjalankan tugas dibidang masing-masing untuk lebih ulet, terampil, cekatan, berdedikasi tinggi dan menuju kepada suatu efisiensi untuk dapat mencapai tujuan nasional yaitu mewujudkan masyarakat adil dan makmur yang merata dan berkesinambungan baik materil maupun spiritual.

Berlakunya UU Nomor 32 Tahun 2004 tentang otonomi daerah telah memberikan arah perubahan dalam penyelenggaraan pemerintahan. Setiap daerah diberi kewenangan dan dituntut untuk meningkatkan kemandirian daerah baik dalam hal keuangan maupun kualitas sumber daya manusianya. Pemerintah daerah harus berupaya untuk lebih meningkatkan kualitas sumber daya aparatur disegala bidang karena peran sumber daya manusia diharapkan dapat meningkatkan kinerja organisasi dalam memberikan pelayanan prima kepada masyarakat

Bentuk-bentuk ikatan persekutuan hidup telah berkembang dan menjadi lebih beragam. Kini kerja sama di sampingmemenuhi kebutuhan menjaga kelangsungan hidup dan rasa aman, juga untukmemperoleh kasih sayang dan persahabatan seperti dalam keluarga danpaguyuban, juga telah digunakan untuk mencapai tujuan-tujuan tertentu yangdiinginkan, seperti nampak organisasi-organisasi yang resmi. Koperasi mempunyai tujuan yang utama ialah meningkatkan taraf hidupdan kesejahteraan anggota-anggotanya. Pada asasnya koperasi bukanlah suatu usaha yang mencari keuntungan semata-mata seperti halnya usaha-usaha swastaseperti firma dan perseroan. Berbicara mengenai koperasi sangat berkaitan dengan ekonomi, mengingatteori ekonomi sering kali belum mampu memberikan jawaban-jawaban 
yangmemuaskan terhadap masalah-masalah yang dihadapi dalam menganalisis danmembangun koperasi, perlu disadari bahwa fakta menunjukkan organisasiorganisasikoperasi hanya mencakup suatu bagian dari semua kegiatan ekonomi,dan koperasi akan dapat hidup hanyalah dalam kondisi yang sangat khusus. Asumsi manusia rasional merupakan dasar dari pemikiran ekonomi,sehingga setiap kegiatan ekonomi yang dilakukan oleh manusia yang rasionalakan berprinsip pada prinsip ekonomi yaitu menggunakan sumber yang terbatasuntuk mencapai hasil yang maksimal. Terutama dalam koperasi adanya prinsipprinsipyang diterapkan dalam sebuah koperasi. Untuk terlaksananya prosesekonomi dalam sebuah koperasi yang baik maka faktor lain yang sangatmenentukan adalah terciptanya suatu koperasi dengan pengelolaan organisasiyang lebih efektif.

KODAM III/SILIWANGI (9/4),- Pangdam III/Siliwangi Mayjen TNI Dedi Kusnadi Thamim menekankan guna mewujudkan koperasi yang sehat para pengurus harus memiliki tiga sehat koperasi, yaitu sehat mental (jujur, adil dan bertanggungjawab), sehat organisasi (manajemen terbuka) dan sehat usaha (pelayanan baik dan melaksanakan azas dan sendi koperasi). Penekanan tersebut disampaikan Pangdam III/Siliwangi saat membuka Rapat Anggota Tahunan (RAT) Pusat Koperasi Kartika Siliwangi ke-55 tutup buku tahun 2014, di aula Zidam III/Siliwangi, Jalan Jawa No. 15 Bandung, Selasa (7/4).

Harapan Pangdam, sebagai organisasi yang berbadan hukum maka Puskop Kartika Siliwangi dibenarkan untuk melakukan kegiatan di berbagai bidang usaha, yang diharapkan mampu berkompetisi dan berdampingan dengan pelaku ekonomi lainnya. Untuk itu, para pengurus hendaknya memiliki naluri bisnis dan senantiasa mampu menangkap peluang pasar yang ada, sehingga menghasilkan profit yang optimal . Untuk mewujudkan koperasi yang sehat dan mampu menghasilkan profit yang optimal, serta mampu bersaing dengan badan usaha lainnya, menurut Pangdam, perlu adanya pembenahan di segala bidang yang meliputi pembenahan organisasi, sumber daya manusia (sdm), manajemen dan penempatan serta pembinaan personel yang memiliki kualifikasi kewirausahaan. Hal ini sesuai dengan tema RAT, yaitu: "Dengan Semangat Kebersamaan Dan Soliditas Jaringan Usaha, Kita Tingkatkan Peran Koperasi Kartika Guna Menunjang Kesejahteraan Pra-Jurit Beserta Keluarganya "

\section{KAJIAN PUSTAKA}

Istilah kesejahteraan erat kaitannya dengan tujuan Negara Indonesia. Negara didirikan, dipertahankan dan dikembangkan untuk kepentingan seluruh rakyat yaitu untuk manjamin dan memajukan kesejahteraan umum. Hal ini secara nyata dituangkan dalam pembukaan UUD 1945 yang berbunyi: "kemudian daripada itu untuk membentuk suatu pemerintah Negara Indonesa yang melindungi segenap bangsa Indonesia dan seluruh tumpah darah Indonesia dan untuk memajukan kesejahteraan umum, mencerdaskan kehidupan bangsa dan ikut melaksanakan ketertiban dunia berdasarkan kemerdekaan, perdamaian, abadi dan keadilan sosial, maka disusunlah kemerdekaan kebangsaan Indonesia itu dalam suatu Undang-Undang dasar Negara Indonesia" Komando Daerah Militer III/Siliwangi (sering disingkat Kodam III, Kodam Siliwangi, atau Kodam III/Siliwangi) merupakan Komando Kewilayahan Pertahanan yang meliputi provinsi 
Jawa Barat dan provinsi Banten. Markas Komando berada di Jl. Aceh No. 69 Kota Bandung, Provinsi Jawa Barat. Pangdam III/Siliwangi yang sekarang menjabat adalah Mayjen TNI Muhammad Herindra yang sebelumnya menjabat Komandan Jenderal Komando Pasukan Khussus. Motto Kodam Siliwangi adalah Esa Hilang, Dua Terbilang.

Penguatan kelembagaan merupakan hal yang sangat penting dalam rangka mewujudkan kelembagaan yang tangguh, dinamis dan mandiri. Dengan adanya penguatan kelembagaan diharapkan diharapkan dapat menggerakkan para pihak untuk berperan serta secara aktif dalam penyelenggaraan organisasi pemerintahan. Selain itu, pembagian peran menjadi lebih jelas, masing-masing pihak mengetahui tugas dan wewenang sehingga system manajemen penyelenggaraan pemerintahan dapat dijalankan secara optimal. (Haris Faozan : 2006). Koperasi adalah badan usaha yang beranggotakan orang-orang atau badan hukum koperasi dengan melandaskan kegiatannya berdasarkan prinsip koperasi sekaligus sebagai gerakan ekonomi rakyat yang berdasarkan azas kekeluargaan, koperasi bertujuan untuk mensejahterakan anggotanya (Purwanto, 2009 : 106).

\section{METODE PENELITIAN}

Pendekatan penelitian yang akan penulis gunakan adalah metode deskkriptif yaitu metode yang setuju pada pemecahan masalah. Sedangkan metode yang akan dipakai dalam pengumpulan data adalah:

Teknik Observasi yang penulis gunakan terutama pada saat studi pendahuluan. Melalui teknik ini gejala-gejala yang nampak pada objek penelitian dapat penulis amati. Sasaran pengamatan penulis adalah tempat dan segala aktivitas Koperasi di ZIDAM III Siliwangi

Teknik wawancara, Wawancara atau interview menurut Suyatna B Atmaja (1990:36) adalah "Proses tanya jawab secara lisan yang merupakan alat pengumpul data yang langsung tentang beberapa jenis data sosial baik yang terpendam maupun manifest." Dalam penelitian ini wawancara penulis gunakan untuk mengumpulkan informasi dari penyelenggara koperasi serta anggota koperasi.

Tekhnik angket, Angket menurut Suyatna B Atmaja (1990:31) yaitu Sejumlah daftar pertanyaan yang diajukan kepada responden pada pengelola kopersi dan anggota koperasi.

Studi dokumentasi,Penggunaan studi dekumentasi dalam penyusunan karya ilmiah sangat perlu, karena semua kegiatan yang menyangkut penelitian untuk menguatkan karya tersebut.

\section{HASIL DAN PEMBAHASAN}

Berdasarkan hasil observasi dan wawnacara yang telah peneliti lakukan, strategi penguatan kelembagaan Koperasi Anggota ZIDAM III/ Siliwangi Melalui Penguatan Kelembagaan Koperasi Kartika Yudha Karya Jaya, meliputi : Optimalisasi peranan dan kinerja kelembagaan koperasi Perluasan jaringan kelembagaan dan usaha. Berdasarkan fungsi dan kelembagaan koperasi Anggota ZIDAM III/ Siliwangi Melalui Penguatan Kelembagaan Koperasi Kartika Yudha Karya Jaya serta hasil evaluasi internal dan eksternal keberadaan dan peranan koperasi memiliki potensi sebagai kekuatan dan 
peluang serta memiliki kendala sebagai kelemahan dan ancaman. Berdasarkan perkembangan dan keadaan koperasi mulai berdiri sampai sekarang. Dengan demikian, keseriusan dan ketulusan untuk berpihak kepada kepentingan anggota merupakan syarat mutlak untuk bisa meningkatkan kesejahteraan dan kemandirian sehingga akan menimbulkan kebanggaan sebagai anggota koperasi Zidam III Siliwangi

\section{KESIMPULAN}

Manfaat koperasi merupakan output dari pelaksanaan fungsi-fungsi kegiatan koperasi di dalam melayani anggota pengorganisasian (entrepreneurial-organisational aspects). Skala kegiatan ekonomis tercapai melalui koperasi karena koperasi merupakan kerjasama kegiatan ekonomi yang sama dari seluruh anggota yang tergabung di dalamnya. Dengan demikian, pembentukan suatu koperasi merupakan keputusan untuk membangun suatu aliansi strategis atau intercompany cooperation di antara nelayan guna mencapai keunggulan kompetitif. Saran dari peneliti : Setiap program pemerintah hendaknya bersifat terpadu antar instansi terkait, sehingga tidak menimbulkan kesalahpahaman diantara para pelaksana program serta mendorong kemandirian dan partisipasi masyarakat secara optimal. Pengurus dan anggota koperasi sebaiknya diberi bekal pendidikan dan pelatihan tentang perkoperasian yang memadai.

\section{DAFTAR PUSTAKA}

Huraerah,(2006 ), Pemberdayaan masyarakat, Rineka Cipta, Jakarta

Direktorat PKBM Provinsi Jawa Barat,( 2006) Panduan PKBM, Lubuk Agung, Jakarta

Korten dan Carner (1993) Konsep Pembangunan, Rosda Karya, Bandung

Mulyono, D. (2018). The Strategy Of Managers In Moving Business Learning Group Program In PKBM Srikandi Cimahi City. Journal of Educational Experts (JEE), $1(1), 37-44$.

Sulistiyani, (2004), Pemberdayaan Masyarakat, Transito, Bandung

Kimbangwil Pusat,(2000), Kesejahteraan Masyarakat Juknis P3D

Winarno Surakhmad (1981), Metode Penelitian, Bumi Aksara Jakarta.

Widiastuti, N., \& Kartika, P. (2018). PENERAPAN MODEL KELOMPOK USAHA KREATIF ISLAMI (KUKIS) DALAM PEMBERDAYAAN PEREMPUAN BERBASIS PONDOK PESANTREN. Empowerment, 6(2), 20-29. 